\title{
AGRICULTURAL PRODUCER GROUPS AS MANIFESTATION OF TEAM ENTREPRENEURSHIP IN POLAND
}

\author{
Anna Justyna Parzonko' ${ }^{1}$ PhD; Anna Sieczko², PhD \\ 1,2 Warsaw University of Life Sciences - SGGW
}

\begin{abstract}
The EU agricultural legislation explicitly acknowledges the role of producer organisations for realising the objectives of agricultural business activity. This form of cooperation contributes to strengthening the position of farmers in the economic reality, inter alia by optimising agricultural production costs, adapting to the requirements of foreign markets and obtaining higher prices through collective negotiations. In Poland, poor organization of agricultural producers remains one of the most important problems of Polish agriculture. The aim of this study is to evaluate the current process of forming agricultural producer organizations, with regard to factors conducive to the development of this form of team entrepreneurship as well as barriers causing resignation from this form of cooperation. The paper provides review of problems related to team entrepreneurship in Polish agriculture, presents basic forms of support, discusses the existing advancement of this form of entrepreneurship in Poland and indicates key factors which contribute to the termination of this form of cooperation.
\end{abstract}

Key words: team entrepreneurship, agricultural producer groups, determining factors.

JEL code: $013, \mathrm{Q} 12$

\section{Introduction}

In Polish literature, consideration is given to the phenomenon of a treadmill in agriculture. It is a market mechanism which, despite the continuous efforts of farmers to increase productivity of production factors (e.g. through the implementation of new technologies -technological treadmill) flushes away the benefits of these endeavours because when widespread adoption of new technology takes place, the increased production lowers the price of the commodity for all producers. On the other hand, farmers who resist new technologies and new organizational solutions tend to lag behind and lose competitiveness. Due to the phenomenon of technological treadmill, the main benefits from the implementation of research results and related new technologies to agricultural practice ultimately reach the final consumer, but can also be seized by other, non-agricultural actors, operating in agribusiness, which results in draining of economic surplus from agriculture (Czyzewski B., 2017). Consequently, looking for opportunities to increase the competitiveness of Polish agriculture and boost agricultural incomes, the literature proposes stimulation of concentration processes and improvement of the agrarian structure.

Poland has an unfavourable farm structure in relation to other European Union countries. However, positive changes are taking place in the structure of farms. This is confirmed by the systematic, though slow, decline in the number of farms, mainly those smaller in size (1-10 ha of utilized agricultural area (UAA)) in favour of the largest farms. Nevertheless, in 2014 still more than half of the total number of farms $(52.0 \%)$ were holdings from 1 to 5 ha of UAA. Although a relatively big numerical growth was recorded in the group of relatively big farms, (30 hectares and over and especially 50 hectares and over), they still constitute a small group. In 2014, the percentage of this size of holdings was respectively $5.4 \%$ and $2.4 \%$ and it was almost 2 times lower than the EU-28 average (Karwat-Wozniak B., Chmielizski P., 2016). The decrease in the number of farms resulted in the increase in the average UAA per one farm - from 9.85 ha in 2010 to 10.65 ha in 2017.

The necessity of horizontal integration of farmers results from the mechanisms of the market economy, in which entities have to make economic decisions taking into account the current situation on the market. This is a consequence of both the law of supply and demand as well as the 
growing competition in the food economy. The farmer, like any other producer, strives to obtain the highest possible income in the given market conditions. Small agricultural producers around the world are looking for better ways to organize their farms. Obtaining high incomes is not and will not be possible in the future without seeking solutions that would boost their economic potential by stimulating rural entrepreneurship. One of its manifestations is forming agricultural producer organizations.

The concept of entrepreneurship has a relatively long history (Singh A. P., 2013). In the simplest definition it can be described as the art of coping in life. According to Shane, entrepreneurship involves all activities aiming at the discovery, evaluation and exploitation of opportunities to create future goods and services, or ways of organizing new markets and raw materials through organizing efforts that previously had not existed (Shane S., 2003). Some scientific articles emphasize that it also involves people's activities undertaken to search for new solutions, introduce changes in current activity, utilize emerging opportunities, as well as seek additional and alternative sources of income (Windmill A. P., 1996; Jeczmyk A, Mackowiak M., 2013). Thus, entrepreneurship understood as a form of peoples' activity can involve both individuals and group of associated individuals. The concept of team entrepreneurship can be understood as organized, conscious and voluntary cooperation of people focused on the implementation of a common goal through a more optimal allocation of resources, reduction of production costs (the effect of scale and scope) and strengthening their position on the market (the increase in market share) (Parzonko A. J., 2012). Team cooperation can also reduce transaction costs by improving the level of commercialization (Latynskiy E., Berger T., 2015). Therefore, team entrepreneurship requires close labour relations between people, uses their talents and creative abilities. Agricultural producer organizations are an example of team entrepreneurship, but also cooperatives, partnerships and associations (Kania J., Bogusz M., 2009). According to Kahan, in order for farmers to be entrepreneurial, they need to be innovative and forward-looking, they need to manage their businesses as long-term ventures with a view to making them sustainable and they need to be able to identify opportunities and seize them. The members of producer organizations have to take initiative and be ready to take calculated risks to open or create new markets for their products. They must also be ready to cooperate in a joint production activity and take full responsibility for the result (Kahan D., 2012). Glinka and Gudkova follow the same path of thinking. They believe that being an entrepreneur is a way of life and involves a specific way of looking at the world. It is necessary to have a vision and courage to take action, create opportunities for a more effective use of resources and combine factors of production (Glinka B., Gudkova S., 2011).

Due to the great dispersion of the agricultural sector in Poland, it is important to monitor the integration processes. Taking the above into consideration, the aim of this study is to evaluate the current process of forming agricultural producer organizations, with regard to factors conducive to the development of this form of team entrepreneurship, as well as barriers causing resignation from such cooperation. The research study was based on the literature review, data from the Agency for Restructuring and Modernization of Agriculture (ARiMR) and the Ministry of Agriculture and Rural Development, provisions contained in the EU and Polish legal acts .. 


\section{Research results and discussion}

In Poland's history farmers' teamwork was induced by political regulations (1949-1956), and despite the time distance, the idea still carries strong negative connotations in the minds of today's agricultural producers. In the later years of the socialist economy, the form of cooperation encouraged by the state authorities were individual farmers' teams (1973-1989) and intersectoral cooperatives, established between the agricultural state sector and the individual farmers' sector, which were supposed to remedy the food shortages on the market. The rural cooperatives existed as long as financial incentives were provided to support them, but as the support was reduced, the organizations started to disappear (Mickiewicz A. et al., 2014). In general, in Central and Eastern Europe, farmers perceived agricultural cooperatives as collectivized, almost monopolistic structures formed to realise government intervention schemes and provide a wide range of services, including: food production, raw material supply, incurring loans and marketing of produce (Millnes J., Juhasz J., 2006).

Producer organizations appeared in Poland in the early 1990s. Then, they were formed to defend farmers against the effects of disastrous changes following the introduction of market economy. The emerging groups of agricultural producers began their activities without specific legislation on producer organizations. It was only the Act of 15 September 2000 on producer organisations and associations of producer organisations and amending other acts that set out the rules of forming organizations of agricultural producers and their associations and provided criteria for granting public financial aid to support these organization and their operations. The final shape of the legislation concerning agricultural producer organizations was provided by the Act of 18 June 2004 amending the act on producer organisations and associations of producer organisations and amending other acts. Amendments to the act under consideration and the entry into force of the Council Regulation (EC) No 1698/2005 of 20 September 2005 on support for rural development by the European Agricultural Fund for Rural Development (EAFRD) had a significant impact on the pace of development of this form of entrepreneurship in agriculture (Nowakowska-Grunt J., Parzonko A. J., Kielbasa B., 2016). In 2004, only $1 \%$ of the total number of Polish farmers cooperated within agricultural producer groups (Czapniewska G., 2013). The research study conducted in 2006, on a sample of 600 agricultural producers in the Chelm county (powiat) in eastern Poland showed that the main reasons for farmers to resist cooperation included low awareness and lack of positive experiences in the field of joint action. The surveyed farmers presented mainly conservative attitudes; they declared the intention to join a producer group but only when they could see the benefits of this membership (Oleszko-Kurzyna B., 2007).

In Poland, under the Common Agricultural Policy (CAP), the basic instrument for supporting producer groups after 1 May 2004 was financial assistance from the EU funds assigned to facilitate the setting up, administrative activity and investments of a producer group within the framework of activities included in "Agricultural producer groups" RDP 2004-2006, "Agricultural producer groups" RDP 2007-2013, "Setting-up and development of micro enterprises" RDP 2007-2013, "Increasing the added value of basic agricultural and forestry production" RDP 2007-2013, "Forming producer groups and producer organizations" RDP 2014. The amount of aid granted to agricultural producer groups under the RDP 2004-2006 was PLN 74.4 million and under RDP 2007-2013 it was PLN 361 million (until the end of June 2013). The financial plan of the RDP 2014-2020 provides EUR 402,987,547 for support of agricultural producer groups (http://www.arimr.gov.pl). 
The research on RDP 2007-2013 showed positive aspects of cooperation within agricultural producer groups. Financial support significantly improved the adjustment of production to the food market requirements and Polish farmers noticed the benefits of belonging to the group (Krzyzanowska K., Trajer M., 2011). The theoretical assumptions can be observed in practice. The research study involving Polish farmers associated in agricultural producer organizations showed how they benefited from this cooperation. The benefits include (Cupial M., Szelag-Sikora A., 2012; Ptak A., 2017): better planning of production and adjusting it to the needs of contractors, collective negotiating of prices and payment dates, easier cooperation with the contractors, optimisation of production costs through joint purchases of inputs, joint use of equipment, preparation of products for sale and organization of their sale, better access to information, greater investment opportunities resulting from joint capital and access to EU funds, joint marketing of agricultural products, easier access to preferential loans, support for joining quality systems and promotion of certified products and easier access to training and study tours.

Table 1

Total number of agricultural producer groups created since 2001, in operation and deleted from register - as of 5 January 2018

\begin{tabular}{|c|c|c|c|c|c|}
\hline \multirow{2}{*}{$\begin{array}{c}\text { Province } \\
\text { (Wojewodztwo) }\end{array}$} & \multirow{2}{*}{$\begin{array}{c}\text { Number of } \\
\text { agricultural } \\
\text { producer } \\
\text { groups } \\
\text { registered } \\
\text { since } 2001\end{array}$} & \multicolumn{2}{|c|}{$\begin{array}{c}\text { Agricultural producer groups } \\
\text { in operation }\end{array}$} & \multicolumn{2}{|c|}{$\begin{array}{l}\text { Agricultural producer groups } \\
\text { deleted from register }\end{array}$} \\
\hline & & Number & $\%$ & Number & $\%$ \\
\hline Poland & 1847 & 900 & 49 & 947 & 51 \\
\hline Lower Silesia & 185 & 86 & 46 & 99 & 54 \\
\hline $\begin{array}{l}\text { Kujawy - } \\
\text { Pomerania }\end{array}$ & 120 & 72 & 60 & 48 & 40 \\
\hline Lubelin & 52 & 26 & 50 & 26 & 50 \\
\hline Lubuskie & 82 & 44 & 54 & 38 & 46 \\
\hline kodz & 95 & 80 & 84 & 15 & 16 \\
\hline Malopolska & 27 & 17 & 63 & 10 & 37 \\
\hline Mazovia & 110 & 77 & 70 & 33 & 30 \\
\hline Opole & 161 & 82 & 51 & 79 & 49 \\
\hline Podkarpacie & 61 & 38 & 62 & 23 & 38 \\
\hline Podlasie & 51 & 25 & 49 & 26 & 51 \\
\hline Pomerania & 95 & 41 & 43 & 54 & 57 \\
\hline Silesia & 36 & 18 & 50 & 18 & 50 \\
\hline Swietokrzyskie & 14 & 8 & 57 & 6 & 43 \\
\hline Warmia-Masuria & 125 & 53 & 42 & 72 & 58 \\
\hline Wielkopolskie & 533 & 209 & 39 & 324 & 61 \\
\hline West-Pomerania & 100 & 24 & 24 & 76 & 76 \\
\hline
\end{tabular}

Source: authors'elaboration based on: Rejestr grup producentow rolnych (Register of Agricultural Producer Groups), http://www.arimr.gov.pl (Retrieved on 15 Jan 2018)

As demonstrated in Table 1, there are big disparities in the number of agricultural producer groups operating in individual provinces. Unfortunately, their spatial distribution does not follow the logic that smaller producers decide to cooperate in order to adapt to the needs of today's market. In fact, producer organizations are most popular in regions with thriving agriculture. In provinces with the lowest level of competitiveness of agriculture, such as Swietokrzyskie, Malopolskie or Podkarpackie, where group initiatives would be desirable, changes in the field of integration are 
progressing very slowly. Regional diversification of producer organizations implies the necessity to adjust aid instruments to the character of individual regions.

As shown in Table 1, the process of forming agricultural producer groups in Poland is neither dynamic nor sufficient. Compared to the Member States of the so-called old European Union (EU-15), such as Denmark and France, the proportion of farmers undertaking joint economic activities in Poland is much lower (Prus p. et al., 2014). Moreover, the fact that more than half of the groups created over the last 17 years terminated their cooperation is alarming. It is worth asking question about the reasons. It can be assumed that the motivating factor for setting up and operating agricultural producer groups was the available funding. Currently, financial assistance under the Rural Development Program for the years 2014-2020 has been earmarked only for groups of agricultural producers recognized not earlier than on January 1,2014 . It means, that agricultural producer groups registered until 31 December 2013 will not have access to funding despite meeting all other formal conditions provided in the RDP 2014-2020. It also applies to other activities from the European Agricultural Fund, such as the creation and development of microenterprises or increasing the positive value of basic agricultural and forestry production. This situation for many groups is a serious obstacle in the implementation of statutory objectives, including developing business and marketing skills as well as organizing and facilitating the processes of innovation and environmental protection. In addition, the support is directed to individual natural persons, being agricultural producers, working together as part of a formalized group. Thus, regulations excluding legal persons and entities without legal personality from the financial assistance system within the group of agricultural producers could reduce the number of potential beneficiaries. In addition, to avoid providing operating aid and to maintain the motivating role of support, the maximum duration of support has been limited to five years from the date of recognition of the producer group or organization based on the business plan.

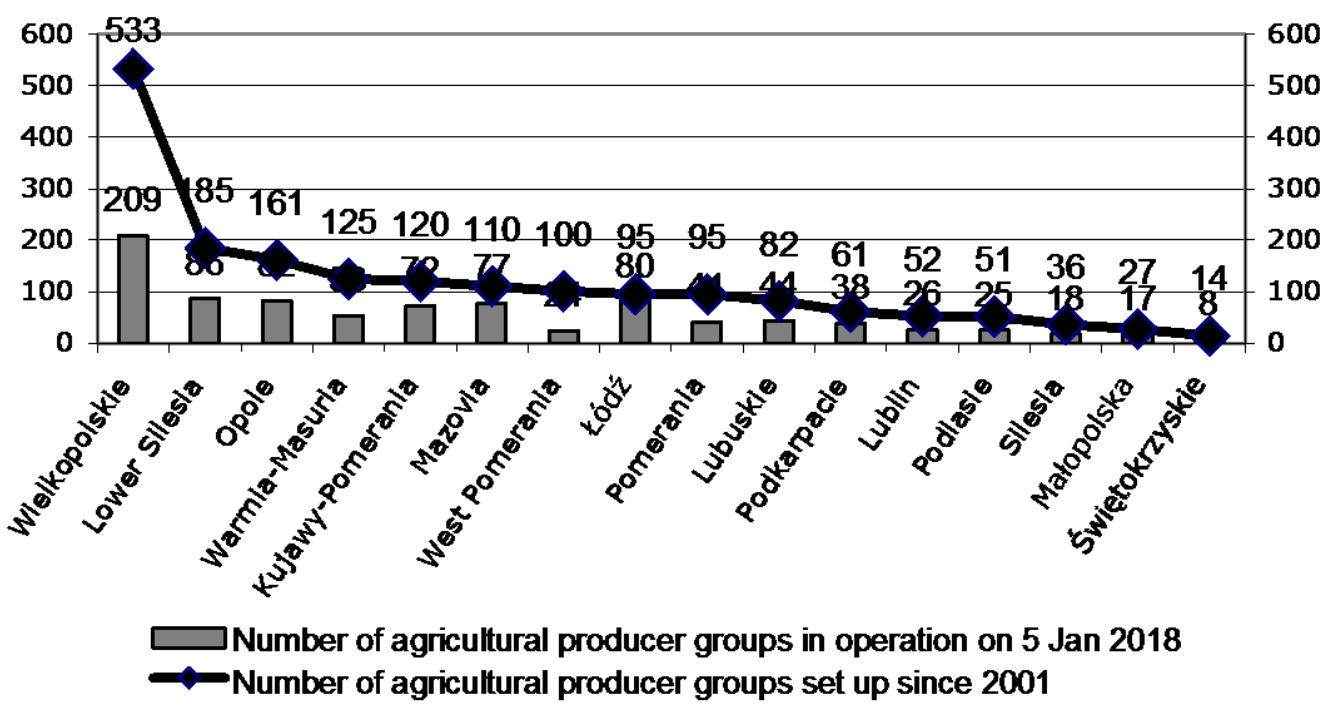

Source: authors' elaboration based on: Rejestr grup producentow rolnych (Register of Agricultural Producer Groups), http://www.arimr.gov.pl (Retrieved on 15 Jan 2018)

Fig. 1. The number of agricultural producer groups formed since 2001 and the number of groups in operation on 5 January 2018

The intention behind the introduced restrictions is well justified. Several years of experience in supporting agricultural producer groups have revealed certain pathologies including low number of members in the registered groups, which is usually at a minimum level of 5 members. In addition, 
dubious effectiveness was recorded in the case of groups formed by legal persons, which were often created by artificial isolation of new entities previously functioning as a whole, whose sole purpose was to obtain support (Bala D., 2016). The data presented in Figure 1 show that farmers from provinces with the most unfavourable agrarian structure are less likely to form producer groups. Granting financial aid to agricultural producer groups consisting of natural persons is aimed at starting structural changes from the smallest farms. Also, preference in assigning funding is given to agricultural producer groups organized in the form of cooperatives, with the biggest possible number of members in a given category, located in a county (powiat) with high agrarian fragmentation or those planning investments contributing to the implementation of cross-cutting objectives.

\section{Conclusions and recommendations}

The EU regulations encourage farmers to form producer groups. This form of cooperation strengthens the position of agricultural producers in the economic reality, inter alia by optimising agricultural production costs, adapting to the requirements of foreign markets and collective negotiating of prices for their produce.

The conducted analysis demonstrated the following.

- The instruments provided under the Common Agricultural Policy have significantly contributed to the popularization of the idea of agricultural producer groups in Poland.

- The formation of agricultural producer groups in Poland is not a widespread process. Since 2001, only 1.847 groups have been registered, of which only 900 are currently active. This is mainly a consequence of farmers' low awareness of the potential benefits of producer cooperation and lack of positive experiences in the field of joint action in the past. What is more, the entrepreneurial, market oriented attitude is not typical for Polish farmers.

- Taking into account the spatial distribution of producer groups, (the smallest number was recorded in provinces with a highly fragmented agrarian structure and the lowest level of agricultural development), it can be concluded that the barrier limiting the formation of agricultural producer groups is the low economic strength of farms and lack of sufficient production resources.

- Regional diversification of farmers' integration has resulted in the adjustment of aid instruments to the character of individual regions. A particular challenge within the framework of the financial perspective for $2014-2020$ is the popularization of horizontal integration among farms from south-eastern Poland.

- Drawing from literature and available registers, we identified the following factors that may determine the success of a producer group: financial assistance from the EU funds for setting up a producer group and its administrative or investment activities within the period of the group's operation under the Rural Development Program for the years 2004-2006, 2007-2013 and 2014-2020, the number of members forming the producer group, previous experience of members in the field of team cooperation and support received from various institutions, mainly agricultural advisory bodies.

To sum up, the farmers' interest in cooperation within agricultural producer groups is growing, which results in an increasing number of producer organizations. However, attention should be paid to the durability of the emerging entities. 


\section{Bibliography}

1. Bala, D. (2016). Wplyw instrumentow wspolnej polityki rolnej na rozwoj grup producentow rolnych w Polsce $w$ ujeciu regionalnym (The impact of the Common Agricultural Policy Instruments on the Development of Agricultural Producer Groups in Poland - the Regional Approach). Studia Obszarow Wiejskich, Tom 42, pp. 155-164. http://dx.doi.org/10.7163/SOW.42.12. Retrieved on 15 Jan 2018.

2. Karwat-Wozniak, B., Chmielinski, p. (2016). Przemiany w strukturze agrarnej polskiego rolnictwa $i$ wplyw wybranych instrumentow WPR na te procesy (Changes in the Agrarian Structure of Polish Agriculture and the Impact of Selected CAP Instruments on these Processes). Prace Naukowe Uniwersytetu Ekonomicznego we Wroclawiu. Polityka ekonomiczna. No 450, pp. 272-274.

3. Cupial M., Szelag-Sikora A., (2012). Grupy producenckie jako przykład rozwoju sprzedsiebiorczości wspierany funduszami UE na obszarach wiejskich (Producer Groups as an Example of Entrepreneurship Development Supported by EU Funds in Eural Areas). Zarzadzanie i Finanse Vol.1, No. 2, pp. 257-267.

4. Czapniewska, G. 2013. Grupy producentow rolnych w rozwoju obszarow wiejskich Pomorza (Groups of Agricultural Producers in the Development of Pomeranian Rural Areas). ACTA Universitatis Lodziensis, Folia Geographica Socio-Oeconomica, No 13, p. 166.

5. Czyzewski, B. (2017). Kierat rynkowy w europejskim rolnictwie (Market Treadmill in European Agriculture). Warszawa: Wydawnictwo Naukowe PWN SA, pp. 16-17.

6. Glinka, B., Gudkowa, S. (2011). Przedsiebiorczosc (Entrepreneurship). Warszawa: Wydawnictwo Oficyna Wolters Kluwer Business, p. 53.

7. Horter, T.,(1993). Organisation of Marketing Cooperatives. The Determinants of Success. Acta Hortic No. 340, pp. 155-159.

8. http://www.arimr.gov.pl. Retrieved on 15 Jan 2018.

9. Jeczmyk, A., Mackowiak, M., (2014). Przedsiebiorczosc w agroturystyce (Entrepreneurshin in Agritourism),(In:) Przedsiebiorczosc w turystyce (Entrepreneurshin in Tourism), Snarski, S.J., Jalinik, M., (Ed.). Bialystok: Wydawnictwo EkoPress. pp. 47-59.

10. Kahan, D., (2012). Entrepreneurship in farming. Food and Agriculture Organization the United Nations. Rome. p. 9.

11. Kania, J., Bogusz, M., (2009). Spoleczno-ekonomiczne aspekty funkcjonowania grup producentow rolnych w wojewodztwie malopolskim (Socio-Economic Aspects of the Functioning of Agricultural Producer Groups in the Malopolskie Province), (In:) Rozwoj przedsiebiorczosci i zespolowej dzialalnosci gospodarczej w rolnictwie w swietle integracji z Unia Europejska (The Development of Entrepreneurship and Team Economic Activity in Agriculture in the Light of Integration with the European Union), Zawisza, S. (Ed.). Bydgoszcz: Wydawnictwo Uniwersytet Technologiczno-Przyrodniczy w Bydgoszczy. pp. 181-197.

12. Krzyzanowska, K., Traje,r M., (2011). Pomoc finansowa dla grup producentow rolnych w ramach dzialania 142 „Grupy Producentow Rolnych" PROW 2007-2013 (Financial Aid for Agricultural Producer Groups Under Measure 142 "Agricultural Producer Groups" RDP 2007-2013), (In:) Studies \& Proceedings of Polish Association for Knowledge Management, No. 56, pp. 87-93.

13. Latynskiy, E., Berger, T. (2016). Networks of Rural Producer Organizations in Uganda: What Can Be Done to Make Them Work Better? World Development, Vol. 78, p. 572.

14. Mickiewicz, A., Mickiewicz, B., Wawrzyniak,B.M., (2014). Charakterystyczne cechy rolniczych spoldzielni produkcyjnych funkcjonujacych w latach 1949-2010 (Characteristic Features of Agricultural Production Cooperatives Operating in the Years 1949-2010). Zagadnienia Doradztwa Rolniczego No. 3, pp. 51-71.

15. Millnes, J., Juhasz, J., (2006). Promoting Farmer Entrepreneurship Through Producer Organizations in Central and Eastern Europe. Food and Agriculture Organization the United Nations, Rome, p. 41.

16. Nowakowska-Grunt J., Parzonko A.J., Kiełbasa B., (2016). Determinants of Managing Networks of Organizations in Rural Areas, Czestochowa: Pyblishing Office of Faculty of Management Czestochowa University of Technology. pp. 51-80.

17. Oleszko -Kurzyna, B. (2007). Postawy rolnikow wobec grup producentow rolnych (Farmers' Attitudes Towards Agricultural Producer Groups), Annales Universitatis Mariae Curie-Sklodowska Lublin vol. XLI,11 Section H, pp. 162-175.

18. Parzonko, A.J. (2012). Role of Leadership in Development of Group Enterprise. Proceedings of the International Conference on Management of Human Resources 2012, Management - Leadership - Strategy Competitiveness: Gödöllö, Hungary, 14-15 June, Vol. 1, pp. 249-251.

19. Prus, P., Marcysiak, T., Goszka, W., Wielewska, I., (2014). Działalnosc osrodkow doradztwa rolniczego w procesie integracji poziomej $w$ rolnictwie $w$ opinii członkow grup producentow rolnych (Agricultural Advisory Centers in the Process of Horizontal Integration in Agriculture in the Opinion of Agricultural Producer Group Members), Roczniki Naukowe SERiA 2014,Vol. 16, Issue 3, pp. 242-246.

20. Ptak, A. (2017).Zalety $i$ wady dzialania w grupie producenckiej (Advantages and Disadvantages of Operating within a Producer Group). Farmer No. 01/2017, p. 11.

21. Shane, S. (2003). A General Theory of Entrepreneurship. The Individual-Opportunity Nexus, Edward Elgar Pub., Northampton, p. 3.

22. Singh, A.P. (2013). Factors Influencing Entrepreneurship Among Farming Community in Uttar Pradesh. International Refereed Research Journal Vol. IV, Issue 3, July, pp. 115-116.

23. Wiatrak, A.P. (1996). Przedsiebiorstwo, przedsiebiorca, przedsiebiorczosc (Enterprise, Entrepreneur, Entrepreneurship), (In:) Rola doradztwa w kreowaniu przedsiebiorczosci na obszarach wiejskich (The Role of 
Proceedings of the 2018 International Conference "ECONOMIC SCIENCE FOR RURAL DEVELOPMENT" No 47

Jelgava, LLU ESAF, 911 May 2018, pp. 221-228 DOI 10.22616/ESRD.2018.026

Advisory Services in Creating Entrepreneurship in Rural Areas ), Wiatrak ,A.P. (Ed.), Warszawa: Wydawnictwo SGGW. pp. 7-16. 